\title{
Fin spine metals by LA-ICP-MS as a method for fish stock discrimination of Genidens barbus in anthropized estuaries
}

\author{
Esteban Avigliano $^{\mathrm{a}, *}$, Nathan Miller ${ }^{\mathrm{b}}$, Barbara Maichak de Carvalho $^{\mathrm{c}}$, Sofía Córdoba Gironde ${ }^{\mathrm{d}}$, \\ Andrea Tombari ${ }^{\mathrm{d}}$, Alejandra V. Volpedo ${ }^{\mathrm{a}}$ \\ a Instituto de Investigaciones en Producción Animal (INPA-CONICET-UBA), Facultad de Ciencias Veterinarias, Universidad de Buenos Aires (UBA), Av. Chorroarín 280 \\ (C1427CWO), Ciudad Autónoma de Buenos Aires, Argentina \\ ${ }^{\mathrm{b}}$ Jackson School of Geosciences, University of Texas at Austin, Austin, TX 78712, United States

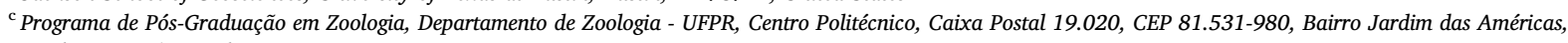 \\ Curitiba, Paraná, Brazil \\ ${ }^{\mathrm{d}}$ Laboratorio de Tecnología de Alimentos y Biotecnología, Sede Atlántica, Universidad Nacional de Río Negro, Ruta Provincial N 1 y Rotonda Cooperación (R8500FAL), \\ Viedma, Río Negro, Argentina
}

\section{A R T I C L E I N F O}

Handled by B. Morales-Nin

Keywords:

Anadromous

Endangered fish

Non-lethal method

Fish stock

Spine microchemistry

\begin{abstract}
A B S T R A C T
Metal:Ca ratios (Li:Ca, Cu:Ca, Fe:Ca, Na:Ca, Rb:Ca, Pb:Ca and $\mathrm{Zn}: \mathrm{Ca}$ ) in fin spines of Genidens barbus, an endangered catfish species, were used as possible habitat markers from three Southwestern Atlantic sampling areas (Paranaguá estuarine complex, Brazil; Paraná River Delta, Argentina-Uruguay; and Negro River, Patagonia). Significant differences $(p<0.05)$ among sites for metal:Ca ratios support the utility of two prospective indicators: (1) habitat - outer $45 \mu \mathrm{m}$ of spine edge and, (2) fish stock - outer $\sim 600 \mu \mathrm{m}$ of spine. Multivariate analysis (MANOVA and PERMANOVA, $p<0.05$ ) and lineal discriminant function analysis (LDA) proved relatively effective for discriminating both habitat (classification rate: 73\%) and fish stock (classification rate: $66 \%$ ) between sampling sites. Classification success improved to $85 \%$ (habitat) and 96\% (fish stock) when LDAs incorporating Sr:Ca, Ba:Ca, Mg:Ca and Mn:Ca) from previous research (same samples) were performed. These results support the use of metal:Ca ratios in G. barbus fin spines as a non-lethal tool for discriminating habitat use and stocks of this endangered catfish. This approach may be applicable to other vulnerable species in polluted habitats.
\end{abstract}

\section{Introduction}

Habitat degradation and overexploitation have induced the collapse of several fisheries, causing conservation problems for some endangered species. One of these is the amphidromous white sea catfish Genidens barbus (Lacepède, 1803) in southwestern Atlantic coastal regions of South America. Formerly an important fishery, decades of overexploitation and poor management have led to progressive catch declines off Brazil and Argentina. In Patos Lagoon (Brazil), for example, captures declined by $98 \%$ between 1973 (9000 tons/year) and 1996 (200 tons/year) (Velasco et al., 2007; IBAMA, 2009). Capture and marketing of the catfish were prohibited from Brazilian waters in 2015 and the species was classified as vulnerable and added to Brazil's Red List of endangered species (MMA 2014). Argentine scientists classified this species as vulnerable in 2012 (Baigún et al., 2012).

Otolith microchemistry has been widely used to understand the habitat ranges and ecology of fish species and associated fisheries (Campana, 1999; Cadrin et al., 2013; Avigliano and Volpedo, 2016). For G. barbus, otolith chemistry has been applied to understand aspects of the life history (Avigliano et al. 2015c; Avigliano et al. 2017b; Avigliano et al. 2020), including identification of stocks (Avigliano et al., 2015b, Avigliano et al., 2017c) and nursery habitats (Avigliano et al., 2015b; Avigliano et al., 2016). Growth histories recorded in dorsal fin spines have been shown to offer attractive, potentially nonlethal, alternatives to otoliths for studying biological aspects of some endangered species (Veinott et al., 1999; Clarke et al., 2007; Allen et al., 2009; Smith and Whitledge, 2010; Jarić et al., 2011; Phelps et al., 2012; Wolff et al., 2013; Rude et al., 2014). Fin spines are mainly composed of calcium phosphate (hydroxyapatite) and collagen (Tzadik et al., 2017), but unlike otoliths, resorption through life can alter their primary compositions. However, marginal areas of spines are least affected by resorption so may retain chemical compositions obtained

\footnotetext{
* Corresponding author.

E-mail address: estebanavigliano@conicet.gov.ar (E. Avigliano).
} 
during growth (Clarke et al., 2007; Luque et al., 2017; Tzadik et al., 2017). Indeed, Avigliano et al. (2019a) found significant chemical relationships between G. Barbus otolith and spine, indicating that spine edge chemistry is related to surrounding water and that is sufficiently stable in relation to the otoliths, where there is apparently no significant resorption.

Avigliano et al. (2019a) demonstrated that natural trace element:Ca markers previously used in G. barbus otolith studies (Ba:Ca, $\mathrm{Mg}: \mathrm{Ca}$, $\mathrm{Mn}: \mathrm{Ca}, \mathrm{Sr}: \mathrm{Ca}$ ) were similarly effective in spines for stock identification within coastal estuaries of the southwestern Atlantic region. If present at concentrations higher than otoliths, analysis of industrial metals associated with anthropogenic activities (e.g., $\mathrm{Cu}, \mathrm{Zn}, \mathrm{Pb}$ ) together with used in previous studies natural metals, could further improve population classification models when spines are used in contaminated habitats. In this regard, anomalously high industrial metal concentrations of metals from industrial origins in water (e.g. $\mathrm{Pb}$ ) and sediment (e.g., $\mathrm{Fe}, \mathrm{Cu}, \mathrm{Zn}, \mathrm{Pb}$ ) have been reported in several Southwestern Atlantic coastal estuaries (Villar et al., 1999b, a; Camilión et al., 2003; Ronco et al., 2008; Avigliano et al., 2019b). Metal:Ca in G. barbus fin spines from three of these estuaries was evaluated to see if spine edge (most recent growth) compositions can be used to effectively discriminate habitat use and stocks. In this effort, a mix of both less-traditional ratios (Li:Ca, Cu:Ca, Fe:Ca, Na:Ca, Rb:Ca, Pb:Ca Zn:Ca) in spines and these previously used by Avigliano et al. (2019a) such as Sr:Ca, Ba:Ca, Mg:Ca and Mn:Ca was used for the first time. Analytical analyzes of metal:Ca ratios were based on the same samples previously used by Avigliano et al. (2019a) and new statistical analysis were performed to evaluate those providing maximum habitat discrimination.

\section{Materials and methods}

\subsection{Sampling}

Fifty-seven fish were collected (Nov 2017 to Jan 2018) using longlines and fishing rods from three disparate estuarine environments, each separated from the next by hundreds of kilometers: Paranaguá Estuarine Complex (PEC), Brazil (20 fish); Paraná River Delta (PRD),Argentina-Uruguay (16 fish) and Negro River (NR), Patagonia, Argentina (21 fish). These estuaries were selected because they are related to different stocks which can be delimited using microchemistry of calcified structures (Avigliano et al., 2017c; Avigliano et al., 2019a). Each of these environments (Fig. 1 ) has a unique inland physicochemical (Table 1) and geographic setting with large urban centers (national or state capitals), and agricultural and industrial activities. PEC (612 km², Lana et al. (2001)) belongs to the Mountain Atlantic rainforest region. PRD with an area of $14,000 \mathrm{~km}^{2}$ is one of South America's largest deltas. PRD belongs to the template Paraná flooded savanna and is part of the UNESCO Biosphere Reserve (BRDelta). NR runs through the Patagonian steppe from the Andes to the Atlantic Ocean.

After recording specimen weight and length, dorsal spines and lapilli otoliths were extracted. First dorsal spines were sampled by cutting $\sim 30 \mathrm{~mm}$ above the condyle base (field observations support that cuts at this level are non-lethal to this species). Spines were cleaned of any remaining tissue with a plastic toothbrush, rinsed with distilled water and air-dried. Mean fish total length \pm SD and range (in $\mathrm{cm}$ ) were $48.4 \pm 5.2$ (37.0-58.0) for PEC, $55.8 \pm 8.2$ (37.0-67.0) for PRD, and $40.8 \pm 4.2(32.3-49.1)$ for NR.

\subsection{Fish aging}

To assess potential impacts of spine age on results, fish specimen ages were determined by counting otolith annuli (Reis, 1986). After embedding in crystal epoxy resin, otoliths were transversely sectioned using a low speed diamond saw. Annuli were counted in transmitted light using a stereomicroscope (Leica ${ }^{\circledR}$ EZ4-HD, Singapore) at $40 \mathrm{X}$ magnification while otoliths were immersed in ultrapure water. In terms of age criteria, the protocol previously reported by Avigliano et al. (2017a) for G. barbus was used to ageing the specimens. Mean age $\pm \mathrm{SD}$ and range (in years) were $7.3 \pm 1.17$ (6-10) for PEC, $9.5 \pm 0.97(7-10)$ for PRD, and $7.3 \pm 1.16(6-9)$ for NR.

\subsection{Spine preparation and elemental analysis}

Surface contaminants were removed from dorsal spine surfaces using fine $(9 \mu \mathrm{m}$-grit) sandpaper followed by three cleaning cycles, each consisting of $\mathrm{x}$-minute reaction steps in $3 \% \mathrm{H}_{2} \mathrm{O}_{2}, 2 \% \mathrm{HNO}_{3}$, and ultrapure $(18.2 \mathrm{mOhm} / \mathrm{cm})$ water (Avigliano et al., 2019a). Dried spines were embedded in crystal resin and sectioned transversely ( $40 \mathrm{~mm}$ from the condyle base) with a low speed diamond saw. After fixing to glass slides with crystal resin, spine sections $(700 \mu \mathrm{m}$ thick) were polished using $9 \mu \mathrm{m}$-grit sandpaper then ultrasonically rinsed in ultrapure water and dried.

Metal ratios (Li:Ca, Cu:Ca, Fe:Ca, Na:Ca, $\mathrm{Pb}: \mathrm{Ca}$ and $\mathrm{Zn}: \mathrm{Ca}$ ) in the outer $\sim 600 \mu \mathrm{m}$ of spine edges (Fig. 2) were determined by Laser Ablation Inductively Coupled Plasma Mass Spectrometry (LA-ICP-MS) at the University of Texas at Austin Department of Geosciences (USA) using an ESI NWR193-UC excimer laser ablation system (193 nm, $4 \mathrm{~ns}$ pulse width) coupled to an Agilent 7500ce ICP-MS. Laser transects were oriented radially and moved from spine interiors to spine exteriors at $5 \mu \mathrm{m} / \mathrm{s}$. To minimize temporal aliasing, a rectangular aperture $(15 \times 80 \mu \mathrm{m})$ was used with the long dimension maintained parallel to growth layering along the outward transects. LA-ICP-MS analytical conditions are further detailed in Table S1. Prior to measurement, transect surfaces were preablated using a $100 \mu \mathrm{m}$ spot, scanning at $50 \mu \mathrm{m} / \mathrm{s}$. Oxide production rates, as monitored by ThO/Th on NIST 612 during daily tuning, averaged $0.36 \pm 0.04 \%$ over the analysis periods. Sample analysis intervals $(40-60 \mathrm{~min})$ were bracketed by replicate ( 2 or 3) analyses of standards, including USGS MACS-3, USGS MAPS-4 and NIST 612. Measured intensities were converted to elemental concentrations $\left(\mu \mathrm{g} / \mathrm{g}\right.$ ) using Iolite software (Paton et al., 2011), with ${ }^{43} \mathrm{Ca}$ as the internal standard with an index values of $17 \mathrm{wt} \%$ (Avigliano et al., 2019a), and USGS MAPS-4 as the primary calibration standard. Recoveries for MACS-3 and NIST 612 were typically within $5-10 \%$ of GeoREM (http://georem.mpch-mainz.gwdg.de) preferred values (Table S2). Analysis of reference materials showed good agreement with the following element recovery rates: ${ }^{7} \mathrm{Li}=88 \%,{ }^{23} \mathrm{Na}=95 \%$, ${ }^{208} \mathrm{~Pb}=92 \%$ and ${ }^{66} \mathrm{Zn}=95 \%$. Precision was estimated by the relative standard deviation percentage of MACS-3 replicates $(N=15)$, where values below $5 \%$ (except for ${ }^{85} \mathrm{Rb}$, which was excluded from further analysis) were obtained (Table S2). Limits of detection $(\mu \mathrm{g} / \mathrm{g}$ ) inferred as a measure of the standard deviation of the estimated baseline intensity during the external standard measurements were 0.11 for ${ }^{63} \mathrm{Cu}$, 0.27 for ${ }^{7} \mathrm{Li}, 8.5$ for ${ }^{23} \mathrm{Na}, 0.30$ for ${ }^{208} \mathrm{~Pb}$ and 0.36 for ${ }^{66} \mathrm{Zn}$ (Table S2). We excluded ${ }^{63} \mathrm{Cu}$ from further analysis because levels proved to be near or below detection limits in the spine edges sampled. We also excluded ${ }^{57} \mathrm{Fe}$ from further analysis because of prominent polyatomic interferences associated with $\mathrm{Ca}$ and $\mathrm{Ar}$ species (e.g., ${ }^{40} \mathrm{Ar}^{16} \mathrm{OH}$, $\left.{ }^{40} \mathrm{Ar}^{17} \mathrm{O},{ }^{38} \mathrm{Ar}^{18} \mathrm{OH},{ }^{40} \mathrm{Ca}^{16} \mathrm{OH},{ }^{40} \mathrm{Ca}^{17} \mathrm{O}\right)$. Elemental concentrations were converted to metal:Ca ratios $(\mu \mathrm{mol} / \mathrm{mol}$ or $\mathrm{mmol} / \mathrm{mol})$.

\subsection{Statistical analysis}

Mean metal:Ca values for the outer $45 \mu \mathrm{m}$ of the spine edge were evaluated as potential habitat markers of the most recently occupied habitat. According to Avigliano et al. (2019a), this ablation length was enough to represent the catch areas within the three regional estuarine settings. Metal:Ca ratios were tested for normality and homogeneity of variance using Shapiro-Wilk and Levene tests, respectively. Only the spine Na:Ca ratio met both normality and homogeneity (Shapiro-Wilk and Levene's, $p>0.05)$. The Li:Ca and Zn:Ca met both normality and homogeneity assumptions after $\log (\mathrm{x}+1), \sqrt{\mathrm{x}}$ or $1 / \sqrt{\mathrm{x}}$ 


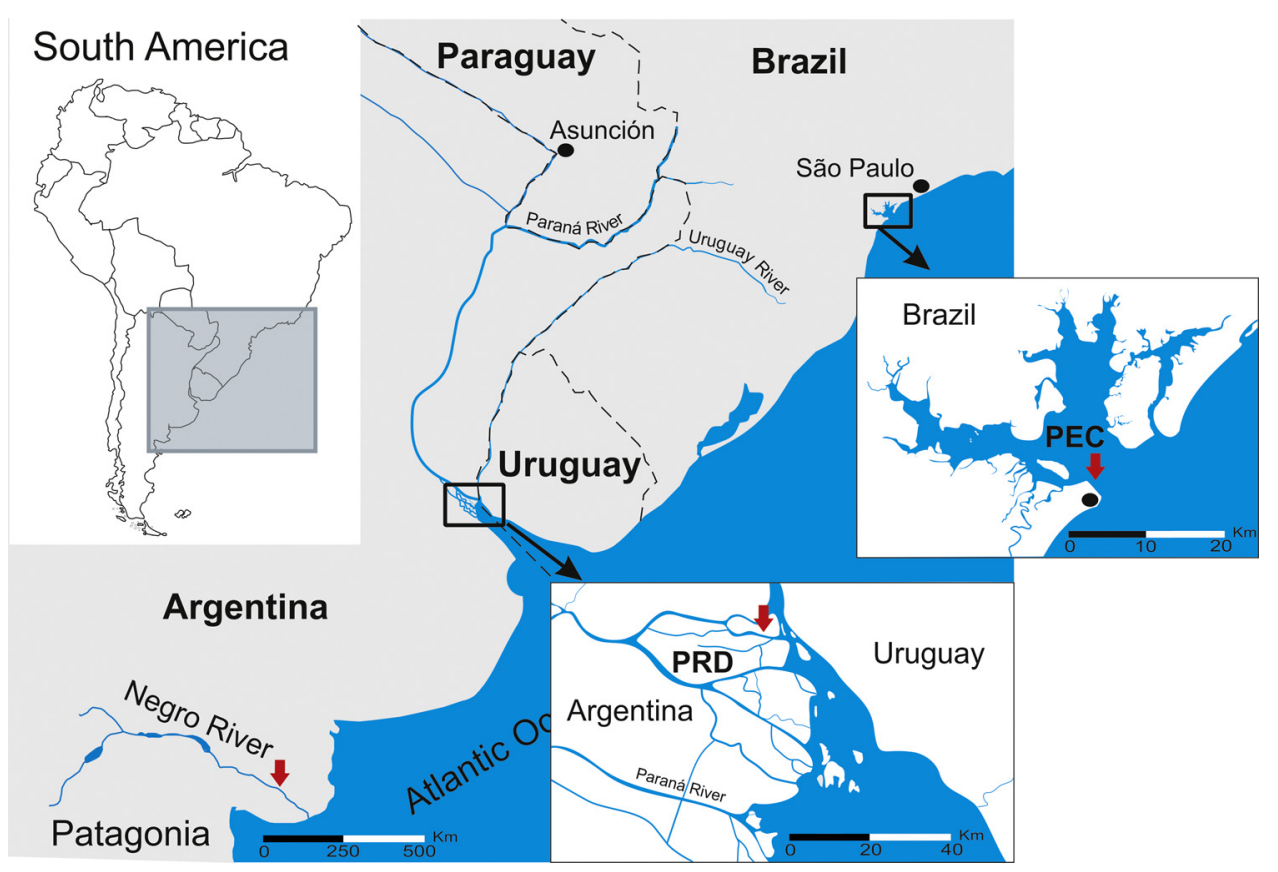

Fig. 1. Map of study area. Red arrows show the sampling sites of Genidens barbus. (For interpretation of the references to color in this figure legend, the reader is referred to the web version of this article.)

transformations, whereas $\mathrm{Pb}: \mathrm{Ca}$ did not meet the assumptions, even after being transformed. To ensure that differences in fish age or size (total length) did not confound spatial patterns in spine elemental composition, the effect of these factors on the elemental ratios was considered using analysis of covariance (ANCOVA) (Cadrin et al., 2013). ANCOVA is robust to violation of homogeneity of variance (Olejnik and Algina, 1984). Only Na:Ca showed a correlation with total length $(F=4.26, p=0.04)$, while the rest of the ratios did not show covariation with size $(0.01<F<1.13,0.29<p<0.91)$ or age $(0.12<<1.36,0.24<p<0.92)$. The Na:Ca effect was corrected by subtracting the common slope $(b=0.13)$ in ANCOVA (Cadrin et al., 2013). Univariate Kruskal-Wallis analysis (non-parametric test) was used to compare spine $\mathrm{Pb}: \mathrm{Ca}$ between sampling sites, while ANOVA (univariate analysis of variance) was used to contrast $\mathrm{Li}: \mathrm{Ca}, \mathrm{Na}: \mathrm{Ca}$, and $\mathrm{Zn}: \mathrm{Ca}$ ratios. Multivariate analyses were used to quantify metal:Ca differences in spine edge compositions among sampling sites. Multivariate analysis of variance (MANOVA, Hotelling's T-square post hoc pairwise comparisons) and Linear discriminant function analysis (LDA) were performed to assess the ability of the elemental compositions to sort fish into specific catch estuaries (habitat indicator).

To carry out a stock assessment, it is necessary to consider a sufficient life time for the analyzed populations to move between the collection sites (Avigliano et al., 2017c; Avigliano et al. 2019a). Then, because $G$. barbus makes annual migrations between different environments (freshwater, estuary and open sea, Avigliano et al., 2017c), the elemental composition of approximately the last year of life (last annuli, $\sim 600 \mu \mathrm{m}$ of spine edges) was used to evaluate the presence of different stocks (Avigliano et al., 2019a). In this case, the statistical treatment described above was performed. Spine Li:Ca, Na:Ca and $\mathrm{Zn:Ca}$ ratios met both assumptions of normality and homogeneity (Shapiro-Wilk and Levene's, $p>0.05$ ). $\mathrm{Pb}: \mathrm{Ca}$ met the assumptions after $\sqrt{\mathrm{x}}$ or transformation. Metal:Ca ratios did not show covariation with total fish length (ANCOVA, $F<0.6, p>0.05$ ). ANOVA (univariate) and MANOVA, followed by Hotelling's T-square Hotelling's Tsquare tests, were performed to detect differences in the spine chemistry between sampling sites. LDA was performed to assess the ability of elemental ratios to classify fish to their potential stocks.

Prior to performing LDAs, multicollinearity was tested by calculating the tolerance value, which was calculated as 1 minus $R^{2}$ of the respective variable with all other variables included in the current model (Hair et al., 2014). Moreover, homogeneity of variance co-variances matrices was verified using Box test (Box, $p>0.06$ ). For all LDA, the expected prior probability classification was based on sample sizes and group numbers (prior probability classifications: 0.35 for the PEC, 0.28 for the PRD and 0.37 for NR) (White and Ruttenberg, 2007) and the classification accuracy was evaluated by leave-one-out crossvalidation. Finally, the mean discriminant coefficient (bj) was used to determine the value of each metal that contributed most to the discrimination (Backhaus et al., 2016).

In addition, LDAs were performed incorporating metal:Ca ( $\mathrm{Sr}: \mathrm{Ca}$, Ba:Ca, Mg:Ca and Mn:Ca) determined by Avigliano et al. (2019a). This data set corresponds to the same spine samples and was obtained in the same analytical run. These DLAs allows evaluating if it is possible to maximize the discrimination by combining different elements.

Statistical tests were performed using the Systat 13 and SPSS 19 programs.

\section{Results}

\subsection{Metal composition as a habitat indicator}

The spine edge (last $45 \mu \mathrm{m}$ ) Li:Ca ratio was significantly higher in PEC than in PRD and NR ( $F=53.68, p<0.0001)$ while, $\mathrm{Pb}$ :Ca was significantly higher in PRD than in PEC and NR $(H=17.4$, $p<0.0002)$. Spine edge Na:Ca ratio was low in PEC, intermediate in NR and high in PRD $(F=4.37, p<0.01)$. No significant differences were found among sites for spine $\mathrm{Zn}: \mathrm{Ca}(F=1.34, p=0.2)$. MANOVA analysis indicated significant multivariate differences between all estuaries ( $F=29, p<0.0001$ ). Jackknifed classifications of LDA were high for PEC (100\%) and moderate for PRD (56\%) and NR (62\%) (total mean $=73 \%$ ). Multivariate analyses suggested that these metal:Ca ratios are effective for discriminating between PEC and PRD habitats, but not between PRD and NR (Table 2 and Fig. 4). Based on mean discriminant coefficients, $\mathrm{Li}: \mathrm{Ca}(\mathrm{bj}=1.06)$ was the most important metal:Ca variable followed by $\mathrm{Na}: \mathrm{Ca}(\mathrm{bj}=-0.62), \mathrm{Pb}: \mathrm{Ca}(\mathrm{bj}=-0.42)$ and $\mathrm{Zn}: \mathrm{Ca}(\mathrm{bj}=0.004)$.

Jackknifed classification success increased (CEP $=100 \%$, $\mathrm{PRD}=75 \%, \mathrm{NR}=81 \%$; overall mean $=85 \%)$ when all ratios $(\mathrm{Ba}: \mathrm{Ca}$, 
Mg:Ca, Mn:Ca, Sr:Ca, Li:Ca, Na:Ca, Pb:Ca and Zn:Ca) were included in the LDA (Table 2 and Fig. 4). Sr:Ca, Ba:Ca, Mg:Ca and Mn:Ca ratios correspond to previously published data (same spine samples).

\subsection{Metal composition as a stock discrimination method}

Spine edge $(\sim$ last annuli or last $600 \mu \mathrm{m}) \mathrm{Li}$ :Ca was higher in PEC than in PRD and NR $(F=93.7, p<0.0001)$. The opposite pattern occurred for $\mathrm{Na}: \mathrm{Ca}(F=6.43, p=0.0013)$ and $\mathrm{Pb}: \mathrm{Ca} \quad(F=7.5$, $p=0.0013$ ), with PEC having lowest values. No significant difference in spine $\mathrm{Zn}$ :Ca occurred between sites $(F=1.6, p=0.6)$. MANOVA results indicated significant multivariate differences between PEC and the other estuaries $(F=11.3, p<0.0001)$. LDA analysis was effective in detecting differences between PEC and PRD or NR (100\% jackknifed classification success) (Table 2 and Fig. 4), suggesting that spine compositions within each estuary were different and thus spatially segregable. Moreover, low/moderate reclassification success were obtained for the PRD $(31 \%)$ and the NR $(67 \%)$ (total mean $=66 \%)$. The most important variable was Li:Ca $(\mathrm{bj}=0.97)$, followed by $\mathrm{Na}: \mathrm{Ca}$ (bj = -0.57), $\mathrm{Pb}: \mathrm{Ca}(\mathrm{bj}=-0.30)$ and $\mathrm{Zn}: \mathrm{Ca}(\mathrm{bj}=-0.03)$ ratios.

Jackknifed classification success once were higher (CEP $=100 \%$, $\mathrm{PRD}=88 \%$, NR $=100 \%$; overall mean $=96 \%$ ) when all ratios $(\mathrm{Ba}: \mathrm{Ca}$, Mg:Ca, Mn:Ca, Sr:Ca, Li:Ca, Na:Ca, Pb:Ca and Zn:Ca) were included in the LDA (Table 2 and Fig. 4).

\section{Discussion}

The discrimination efficiency of spine edge metal:Ca (selectively or in aggregate) in this study suggested that fish spine elemental composition may provide a useful, potentially non-lethal, approach for discriminating ("elemental composition") among stocks of catfish.

In recent decades, fish spine and ray chemistry have been used as a natural marker to study the environmental biology of several fishes (Tzadik et al., 2017). Sr:Ca, for example, has been used to study the migration of sturgeon (Veinott et al., 1999; Arai et al., 2002; Allen et al., 2009; Jarić et al., 2011; Phelps et al., 2012), and other species (Clarke et al., 2007; Wolff et al., 2013; Rude et al., 2014). Multi-elemental approaches to study population structure or to identify natal origin are now increasingly applied (Clarke et al., 2007; Smith and Whitledge, 2010; Pourang et al., 2018). Clarke et al. (2007), for example used spine $\mathrm{Sr}: \mathrm{Ca}, \mathrm{Ba}: \mathrm{Ca}, \mathrm{Mg}: \mathrm{Ca}$ and $\mathrm{Mn}: \mathrm{Ca}$ ratios to discriminate populations of Thymallus arcticus from Canadian rivers. Recently, Pourang et al. (2018) evaluated Sr, Na, Zn, Fe, K, Mg, Cl, S, and P concentrations in spines as a means to discriminate stocks of Rutilus kutum from the Caspian Sea. In this sense, the present study is one of the first to include the metals like $\mathrm{Li}$ and $\mathrm{Pb}$ in spines, along with others previously employed such as $\mathrm{Na}$ and $\mathrm{Zn}$.

Multivariate metal:Ca analysis of spine edges (last $45 \mu \mathrm{m}$ ) was effective for classifying fish according to their common estuarine capture site in Brazilian and Uruguayan-Argentine waters, indicating that select metal:Ca in spines may be used as habitat markers between some study sites. Although the relatively high classification success (56-62\%) between PRD and NR (Fig. 3) demonstrate difficulties of applying this model between these two sites, these rates are nonetheless higher than the prior probabilities ( 0.28 and 0.37 for PRD and NR, respectively), suggesting a moderate potential to discriminate among areas. Results based on last year suggest the presence of at least two stocks in the study area, while the moderate rate for the NR $(62 \%)$ could indicate some degree of segregation or mixing among stocks.

The perfect $(100 \%)$ classification success obtained for specimens from PEC (Table 2) agree with results obtained by otolith chemistry to discriminate among PEC and PRD groups (Avigliano et al., 2016, 2017c). Using spine Sr:Ca, Ba:Ca, Mg:Ca and Mn:Ca, Avigliano et al. (2019a) reported higher classification accuracies than that obtained here for the same capture sites ( 90 vs $73 \%$ and 81 vs $66 \%$ for $45 \mu \mathrm{m}$ and $\sim 1$ year, respectively). Nevertheless, when all the ratios (Na:Ca, Li:Ca, 

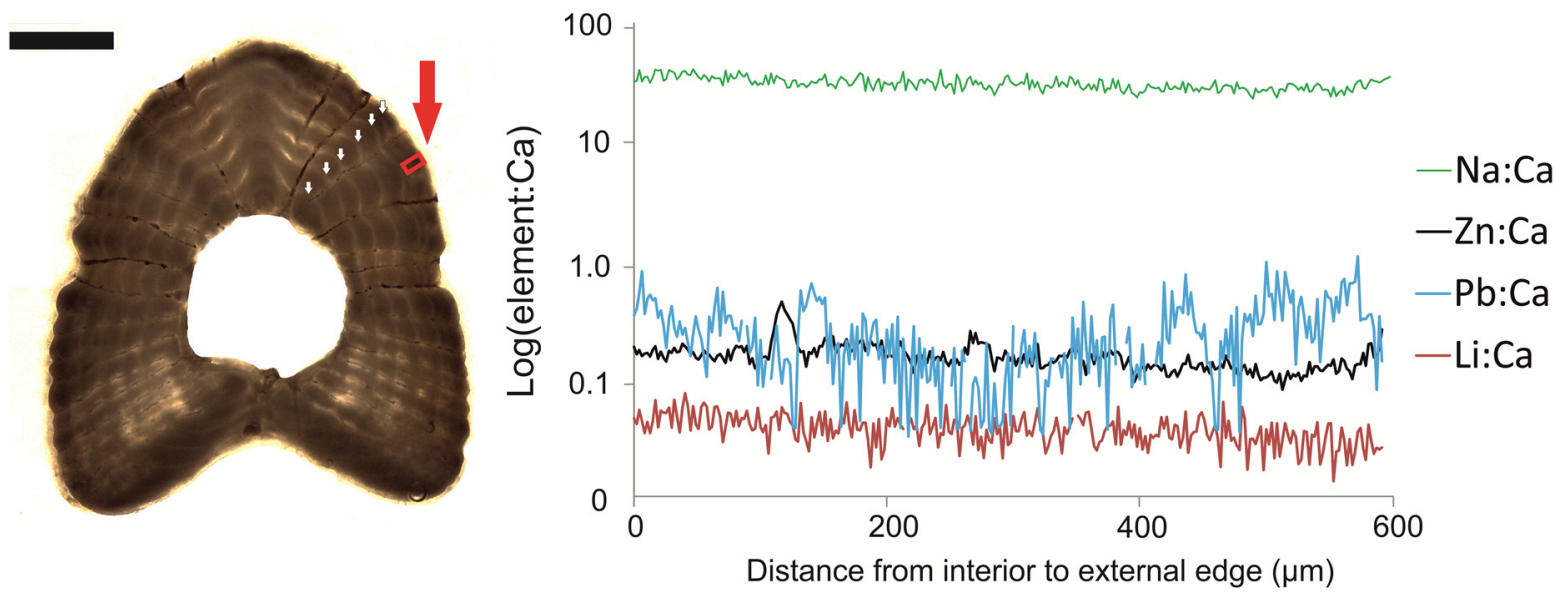

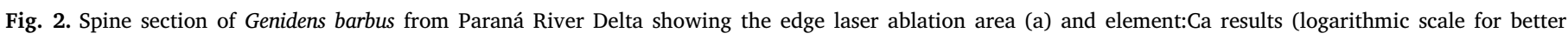

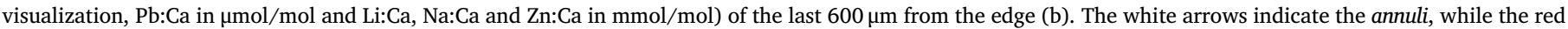

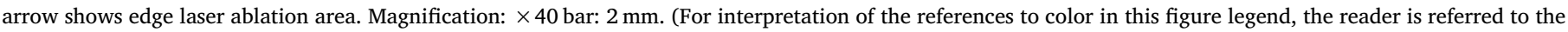
web version of this article.)

Table 2

Cross-classification matrix of the linear discriminant analysis. The numbers represent the Jackknifed classification percentage on the basis of multi-elemental composition of spine edge (last $45 \mu \mathrm{m}$ of the edge and the last year of the fish's life). N: sample size. PEC: Paranaguá estuarine complex (Brazil); PRD: Paraná River Delta (Argentina-Uruguay); NR, Negro River, Patagonia (Argentina).

\begin{tabular}{|c|c|c|c|c|c|c|c|}
\hline \multicolumn{4}{|l|}{$45 \mu \mathrm{m}$} & \multicolumn{4}{|c|}{ Last year } \\
\hline \multicolumn{4}{|c|}{4 elements } & \multicolumn{4}{|c|}{4 elements } \\
\hline & CEP & PRD & NR & & CEP & PRD & NR \\
\hline CEP & 100 & 0 & 0 & CEP & 100 & 0 & 0 \\
\hline PRD & 0 & 56 & 44 & PRD & 0 & 31 & 69 \\
\hline NR & 10 & 29 & 62 & NR & 5 & 29 & 67 \\
\hline Mean & & & 72.6 & & & & 66.0 \\
\hline \multicolumn{4}{|c|}{8 elements } & \multicolumn{4}{|c|}{8 elements } \\
\hline CEP & 100 & 0 & 0 & CEP & 100 & 0 & 0 \\
\hline PRD & 0 & 75 & 25 & PRD & 0 & 88 & 13 \\
\hline NR & 0 & 19 & 81 & NR & 7 & 33 & 100 \\
\hline Mean & & & 85.3 & & & & 96.0 \\
\hline
\end{tabular}

$\mathrm{Zn}: \mathrm{Ca}, \mathrm{Pb}: \mathrm{Ca}, \mathrm{Sr}: \mathrm{Ca}, \mathrm{Ba}: \mathrm{Ca}, \mathrm{Mg}: \mathrm{Ca}$ and $\mathrm{Mn}: \mathrm{Ca})$ were analyzed together, classification accuracies were higher (85.3 and 95.8 for $45 \mu \mathrm{m}$ and $\sim 1$ year, respectively) relative to analyses based on individual metal:Ca (Na:Ca, Li:Ca, Zn:Ca, and Pb:Ca vs Sr:Ca, Ba:Ca, Mg:Ca and Mn:Ca). That this integrated approach better discriminated between PRD and NR populations supports this non-lethal fish spine-based approach for future evaluations of fisheries, particularly for vulnerable species. The similar patterns obtained for the last $45 \mu \mathrm{m}$ and last annuli, are further evidence that the $G$. barbus spine chemistry could be a useful indicator of both habitat and population structure. This could also suggest that the chemistry of the spine edge is stable enough to discriminate the stocks selected for this study.

Trace element incorporation within biological matrices of hydroxyapatite (bioapatite) such as spine and bone, can be influenced by a variety of factors, including water salinity, temperature, and composition (Yamada et al., 1987; Tórz and Nędzarek, 2013; Avigliano et al., 2019a), diet (Kennedy et al., 2000), genetics and physiology (Yamada et al., 1987; Pourang et al., 2018) and trophic level (Emara et al., 1993). Most published studies interpret bioapatite compositions in relation to ambient water characteristics (Tzadik et al., 2017). Positive $(\mathrm{Mn} / \mathrm{Ca})$ and negative $(\mathrm{Mg} / \mathrm{Ca}$ and $\mathrm{Ba} / \mathrm{Ca})$ temperature relationships have been documented in stingray (Urobatis halleri) vertebra (Smith et al., 2013) while, temperature responses were not found for Sr/Ca and $\mathrm{Li} / \mathrm{Ca}$. Opercula $\mathrm{Pb}$ concentrations correlate positively with age and negatively with pH, alkalinity and dissolved Ca (Köck et al., 1996). Skeletal $\mathrm{Cu}, \mathrm{Mn}$ and $\mathrm{Fe}$ concentrations related to tropic level were reported in diadromous fishes like mugilids (Emara et al., 1993). Yamada et al. (1987) reported a genetic influence of $\mathrm{Zn}$ incorporation in Sockeye Salmon (Oncorhynchus nerka) vertebrae. Most dietary studies of metal incorporation within boney structures have been limited to $\mathrm{Sr}$ (Kennedy et al., 2000; Tzadik et al., 2017) and $\delta^{34}$ S (Trembaczowsk and Niezgoda, 2011). Factors influencing the incorporation of metals such as $\mathrm{Li}, \mathrm{Na}, \mathrm{Pb}$, and $\mathrm{Zn}$ into fin spines have not been systematically studied, but environmental factors such as salinity and water composition may partially control $\mathrm{Ba}, \mathrm{Mg}$ and $\mathrm{Sr}$ and other metals (Clarke et al., 2007; Phelps et al., 2012; Tzadik et al., 2017; Avigliano et al., 2019a).

The estuaries studied have different physicochemical parameters (Table 1) and degrees of anthropogenic contamination associated with large urban centers (Choueri et al., 2009; Avigliano et al., 2015a). Avigliano et al. (2015a) and Avigliano and Schenone (2015) reported moderate values of dissolved $\mathrm{Pb}$ (up to $11 \mu \mathrm{g} / \mathrm{l}$ ) and $\mathrm{Zn}$ (up to $90 \mu \mathrm{g} / \mathrm{l}$ ) in water from the PRD system. Avigliano et al. (2015a) reported Li values in PRD system that were relatively low (up to $3 \mu \mathrm{g} / \mathrm{l}$ ). At least in part, the $\mathrm{Li}$ is of natural origin in some areas of the La Plata Basin (Concha et al., 2010). In sediment, high heavy metal values have been reported for the PRD system, for example, 4-63 (in $\mathrm{mg} / \mathrm{kg}$ dry wet) for $\mathrm{Cu}$, up to 27,585 for Fe, 4.2-124 for Pb, 32-387 for $\mathrm{Zn}$ and 345-3026 for $\mathrm{Na}$, depending on the sampling (Villar et al., 1999b, a; Camilión et al., 2003; Ronco et al., 2008). Metal concentrations in PEC and NR waters and sediments have been scarcely studied. In NR, IGRH (2016) reported $\mathrm{Pb}$ concentrations in water below $0.8 \mu \mathrm{g} / 1$ and $\mathrm{Zn}$ concentrations lower than $31 \mu \mathrm{g} / \mathrm{l}$. In the PEC, da Rocha et al. (2017) reported Pb levels in water below $0.2 \mu \mathrm{g} / \mathrm{l}$. The relative $\mathrm{Pb}$ concentrations in water for the three estuaries (PRD > NR and PEC) are consistent with those found in spine $\mathrm{Pb}: \mathrm{Ca}$ in this study. In contrast, $\mathrm{Zn}$ levels in water $(\mathrm{PRD}>\mathrm{NR})$ do not agree with spine $\mathrm{Zn}: \mathrm{Ca}$ values $(\mathrm{PRD}=\mathrm{NR})$.

Spatial variation in spine metal:Ca compositions among the sampling sites likely derive from one or more of the factors detailed above (pollution, natural water composition, genetics, physiology, etc). Temperature has been shown to be a factor in bioapatite metal:Ca composition (e.g., Smith et al., 2013; Tzadik et al., 2017). This could be a significant factor, as the estuaries studied range over 1000s of kilometers from warm tropical to cold temperate regions, with a strong north-to-south decreasing temperature gradient spanning $24^{\circ} \mathrm{C}$ (Table 1). These estuaries also differ in terms of upstream (geographic, 


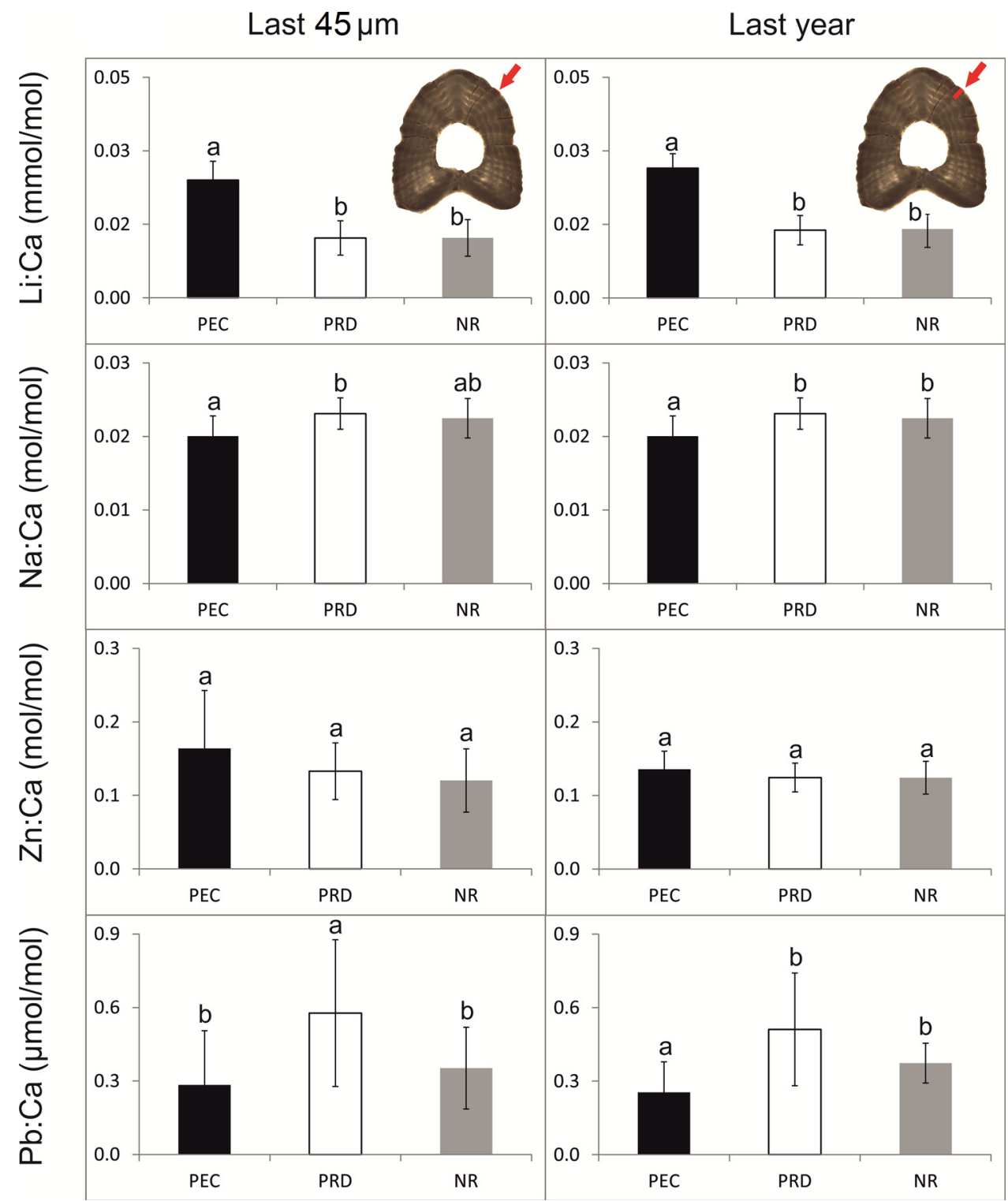

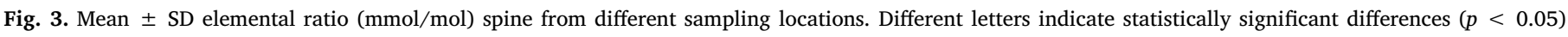
between sampling sites. The red arrows show edge laser ablation area.

population, industry) and other hydrological attributes (depth, salinity, Table 1), which may impact metal uptake in fin spines.

Due to the potential of resorption to variably alter composition, spines have been less used than otoliths (Tzadik et al., 2017). Resorption is clearly an important factor bearing upon the use of fin spines as non-lethal alternatives to otoliths. Resorption may occur repeatedly during life, a vascularization process known as "bone remodeling" that can destroy or obscure annuli in central spine regions, but usually does not occur in exterior spine regions of recent growth (Tzadik et al., 2017). For the studied G. barbus spines, a loss of annuli in centers of some spines that would underestimate age by up to three years compared to corresponding otoliths was observed. Although resorption may over print the compositions of early-formed annuli, the finding that $G$. barbus spine edge compositions compare reasonably with otoliths, indicates that spine edges may be sufficiently stable to be used as natural habitat markers (Avigliano et al., 2019a).

This study first used metal ratios such as Na:Ca, Li:Ca, Zn:Ca, and $\mathrm{Pb}: \mathrm{Ca}$ in spines to study the population structure of G. Barbus. The successful use of these chemical markers suggests that this potentially non-lethal approach may have broader applications for monitoring and discriminating stocks of this, and other endangered fish stocks. Needed are systematic studies of factors influencing metal uptake in spines and of the chemical stability of spines during development, particularly for early stages more susceptible to resorption. Finally, although living specimens without dorsal fin spines have been observed in field, studies are necessary to estimate the mortality rate caused by the extraction of these structures.

\section{CRediT authorship contribution statement}

Esteban Avigliano: Conceptualization, Data curation, Formal analysis, Funding acquisition, Investigation, Methodology, Project administration, Resources, Supervision, Visualization, Writing - original draft, Writing - review \& editing. Nathan Miller: Methodology, Resources, Writing - original draft, Writing - review \& editing. Barbara Maichak de Carvalho: Methodology, Funding acquisition. Sofía Córdoba Gironde: Methodology, Data curation. Andrea Tombari: Methodology, Funding acquisition. Alejandra V. Volpedo: Resources, Writing - original draft, Funding acquisition, Project administration. 

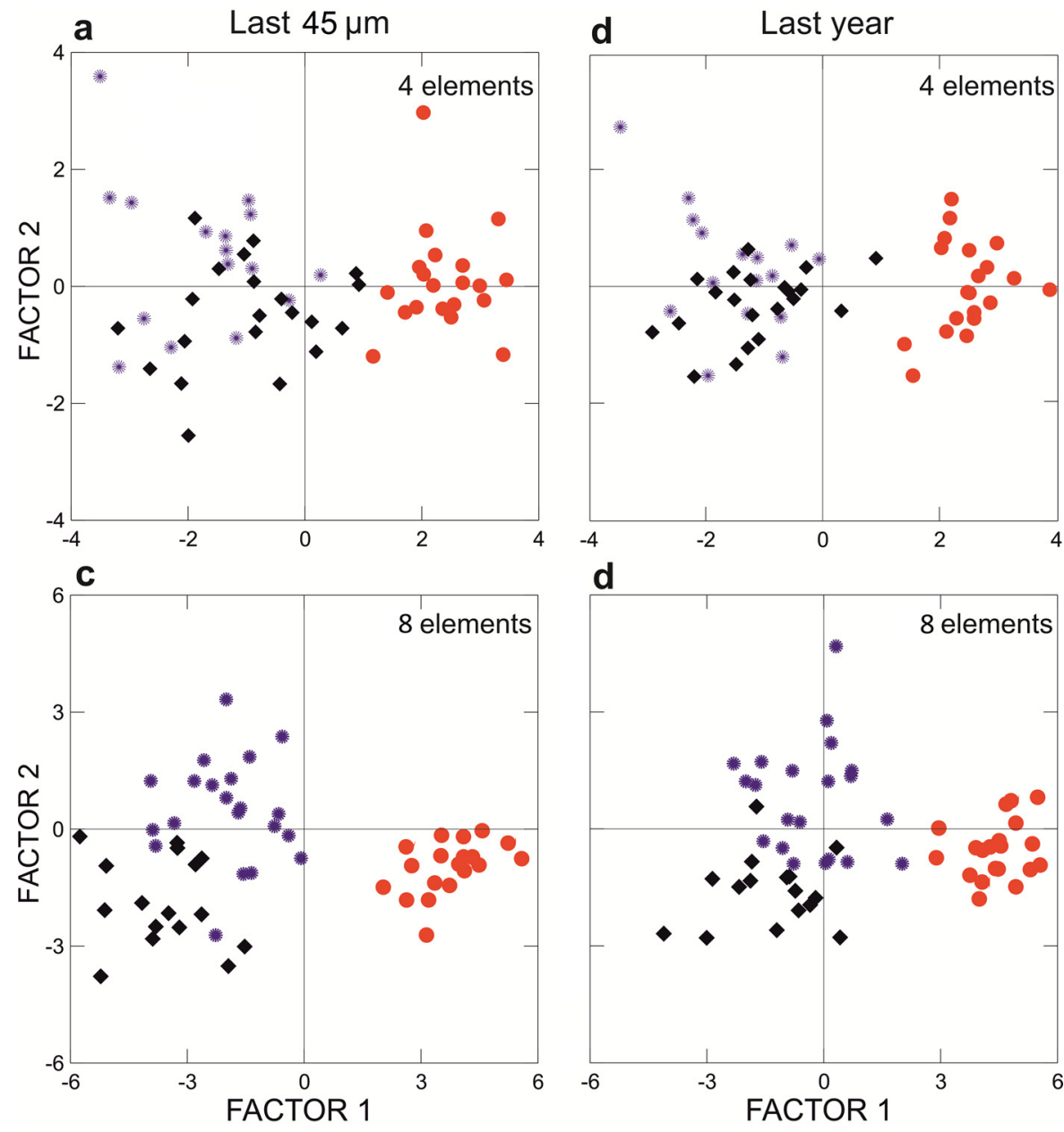

PEC

NR

\section{PRD}

Fig. 4. Linear discriminant analysis of chemistry spine using Na:Ca, $\mathrm{Li}: \mathrm{Ca}, \mathrm{Zn}: \mathrm{Ca}$, and $\mathrm{Pb}: \mathrm{Ca}$ (a and b) and all ratios (Na:Ca, Li:Ca, $\mathrm{Zn}: \mathrm{Ca}, \mathrm{Pb}: \mathrm{Ca}, \mathrm{Sr}: \mathrm{Ca}, \mathrm{Ba}: \mathrm{Ca}$, $\mathrm{Mg}: \mathrm{Ca}$ and $\mathrm{Mn}: \mathrm{Ca})(\mathrm{c}$ and d).

\section{Declaration of Competing Interest}

We have no known competing financial interests or personal relationships that could have appeared to influence the work reported in this paper.

\section{Acknowledgments}

The authors are grateful for funding from the project CAFP-BA/SPU and 292/14 UFPR/ Fundação Araucária. They also thank CONICET, UBACYT and CNPQ for the PhD degree scholarship to the Barbara Maichak de Carvalho (141267/2015-1). The authors also thank the Editor and the anonymous reviewers who made important contributions and suggestions to the paper.

\section{Appendix A. Supplementary data}

Supplementary material related to this article can be found, in the online version, at doi:https://doi.org/10.1016/j.fishres.2020.105625.

\section{References}

Acha, M.E., Mianzan, H., Guerrero, R., et al., 2008. An overview of physical and ecological processes in the Rio de la Plata Estuary. Cont. Shelf Res. 28, 1579-1588. https://doi.org/10.1016/j.csr.2007.01.031.

Allen, P.J., Hobbs, J.A., Cech, J.J., et al., 2009. Using trace elements in pectoral fin rays to assess life history movements in sturgeon: estimating age at initial seawater entry in Klamath River Green Sturgeon. Trans. Am. Fish. Soc. 138, 240-250. https://doi.org/ 10.1577/T08-061.1.

Arai, T., Levin, A.V., Boltunov, A.N., Miyazaki, N., 2002. Migratory history of the Russian sturgeon Acipenser guldenstadti in the Caspian Sea, as revealed by pectoral fin spine Sr:Ca ratios. Mar. Biol. 141, 315-319. https://doi.org/10.1007/s00227-002-0820-y.

Avigliano, E., Schenone, N.F., 2015. Human health risk assessment and environmental distribution of trace elements, glyphosate, fecal coliform and total coliform in Atlantic Rainforest mountain rivers (South America). Microchem. J. 122, 149-158. https://doi.org/10.1016/j.microc.2015.05.004.

Avigliano, E., Volpedo, A.V., 2016. A review of the application of otolith microchemistry toward the study of Latin American fishes. Rev. Fish. Sci. Aquac. 24, 369-384. https://doi.org/10.1080/23308249.2016.1202189.

Avigliano, E., Schenone, N.F., Volpedo, A.V., et al., 2015a. Heavy metals and trace elements in muscle of silverside (Odontesthes bonariensis) and water from different environments (Argentina): aquatic pollution and consumption effect approach. Sci. Total Environ. 506-507, 102-108. https://doi.org/10.1016/j.scitotenv.2014.10.119.

Avigliano, E., Velasco, G., Volpedo, A., 2015b. Use of lapillus otolith microchemistry as an indicator of the habitat of Genidens barbus from different estuarine environments in the southwestern Atlantic Ocean. Environ. Biol. Fishes 98, 1623-1632. https://doi. org /10.1007/s10641-015-0387-3.

Avigliano, E., Velasco, G., Volpedo, A.V., 2015c. Assessing the use of two southwestern Atlantic estuaries by different life cycle stages of the anadromous catfish Genidens barbus (Lacépède, 1803) as revealed by Sr:Ca and Ba:Ca ratios in otoliths. J. Appl. Ichthyol. 31, 740-743. https://doi.org/10.1111/jai.12766.

Avigliano, E., Carvalho, B., Velasco, G., et al., 2016. Nursery areas and connectivity of the adults anadromous catfish (Genidens barbus) revealed by otolith-core microchemistry in the south-western Atlantic Ocean. Mar. Freshw. Res. 68, 931-940. https://doi.org/ 10.1071/MF16058.

Avigliano, E., Carvalho, B., Velasco, G., et al., 2017a. Inter-annual variability in otolith chemistry of catfish Genidens barbus from South-western Atlantic estuaries. J. Mar. Biolog. Assoc. U.K. 1-11. https://doi.org/10.1017/S0025315417000212.

Avigliano, E., Leisen, M., Romero, R., et al., 2017b. Fluvio-marine travelers from South 
America: cyclic amphidromy and freshwater residency, typical behaviors in Genidens barbus inferred by otolith chemistry. Fish. Res. 193, 184-194. https://doi.org/10. 1016/j.fishres.2017.04.011.

Avigliano, E., Maichak de Carvalho, B., Leisen, M., et al., 2017c. Otolith edge fingerprints as approach for stock identification of Genidens barbus. Estuar. Coast. Shelf Sci. 194, 92-96. https://doi.org/10.1016/j.ecss.2017.06.008.

Avigliano, E., Carvalho, B.M., Miller, N., et al., 2019a. Fin spine chemistry as a non-lethal alternative to otoliths for stock discrimination in an endangered catfish. Mar. Ecol. Prog. Ser. 614, 147-157. https://doi.org/10.3354/meps12895.

Avigliano, E., Monferrán, M.V., Sánchez, S., et al., 2019b. Distribution and bioaccumulation of 12 trace elements in water, sediment and tissues of the main fishery from different environments of the La Plata basin (South America): risk assessment for human consumption. Chemosphere. https://doi.org/10.1016/j.chemosphere.2019. 124394.

Avigliano, E., Clavijo, C., Scarabotti, P., et al., 2019c. Exposure to 19 elements via water ingestion and dermal contact in several South American environments (La Plata Basin): from Andes and Atlantic Forest to sea front. Microchem. J. 149, 103986. https://doi.org/10.1016/j.microc.2019.103986.

Avigliano, E., Martínez, G., Stoessel, L., et al., 2020. Otoliths as indicators for fish behaviour and procurement strategies of hunter-gatherers in North Patagonia. Heliyon 6, e03438.

Backhaus, K., Erichson, B., Plinke, W., Weiber, R., 2016. Multivariate Analysemethoden Eine Anwendungsorientierte Einführung. Springer-Verlag, Berlin Heidelberg, Berlin, Germany.

Baigún, C.R.M., Colautti, D., López, H.L., et al., 2012. Application of extinction risk and conservation criteria for assessing fish species in the lower La Plata River basin, South America. Aquat. Conserv. Mar. Freshw. Ecosyst. 22, 181-197. https://doi.org/10. 1002/aqc. 2223.

Cadrin, S.X., Karr, L.A., Mariani, S., 2013. Stock identification methods: an overview. In: Cadrin, S.X., Kerr, L.A., Mariani, S. (Eds.), Stock Identification Methods. Applications in Fishery Science, pp. 3-6.

Camilión, M.C., Manassero, M.J., Hurtado, M.A., Ronco, A.E., 2003. Copper, lead and zinc distribution in soils and sediments of the south-western coast of the Río de La Plata estuary. J. Soils Sediments 3, 213-220. https://doi.org/10.1065/jss2003.04.073.

Campana, S.E., 1999. Chemistry and composition of fish otoliths: pathways, mechanisms and applications. Mar. Ecol. Prog. Ser. 188, 263-297. https://doi.org/10.3354/ meps188263.

Choueri, R.B., Cesar, A., Torres, R.J., et al., 2009. Integrated sediment quality assessment in Paranaguá Estuarine System, Southern Brazil. Ecotoxicol. Environ. Saf. 72, 1824-1831. https://doi.org/10.1016/j.ecoenv.2008.12.005.

Clarke, A.D., Telmer, K.H., Mark Shrimpton, J., 2007. Elemental analysis of otoliths, fin rays and scales: a comparison of bony structures to provide population and life-history information for the Arctic grayling (Thymallus arcticus). Ecol. Freshw. Fish 16, 354-361. https://doi.org/10.1111/j.1600-0633.2007.00232.x.

Concha, G., Broberg, K., Grandér, M., et al., 2010. High-level exposure to lithium, boron, cesium, and arsenic via drinking water in the Andes of Northern Argentina. Environ. Sci. Technol. 6875-6880. https://doi.org/10.1021/es1010384.

da Rocha, M.L., Sa, F., Campos, M.S., et al., 2017. Metals impact into the Paranaguá estuarine complex (Brazil) during the exceptional flood of 2011. Braz. J. Oceanogr. 65, 54-68. https://doi.org/10.1590/S1679-87592017127706501.

Dos Anjos, V.E., da C. Machado, E., Grassi, M.T., 2012. Biogeochemical bbehavior of arsenic species at paranaguá estuarine complex, Southern Brazil. Aquat. Geochem. 18, 407-420. https://doi.org/10.1007/s10498-012-9161-8.

Emara, H.I., El-Deek, M.S., Ahmed, N.S., 1993. A comparative study on the levels of trace metals in some mediterranean and Red Sea fishes. Chem. Ecol. 8, 119-127. https:// doi.org/10.1080/02757549308035985.

Guerrero, R.A., Piola, A.R., 1997. Masas de Agua En La Plataforma Continental. Instituto Nacional de Investigación y Desarrollo Pesquero-INIDEP, Mar del Plata, Argentina.

Hair, J.F., Black, W.C., Babin, B.J., Anderson, R.E., 2014. ) Multivariate Data Analysis: Pearson New International Edition. Pearson new international edition, Harlow, United Kingdom.

IBAMA, 2009. Desembarque de Pescados No Rio Grande Do Sul. Annual Report, Centro de Pesquisa do Rio Grande, Río Grande do Sul, Brazil.

IGRH, 2016. Calidad Del Agua Del Río Negro 2011-2016. Intendencia General de Recursos Hídricos, Río Negro, Argentina. Viedma.

Jarić, I., Lenhardt, M., Pallon, J., et al., 2011. Insight into Danube sturgeon life history: trace element assessment in pectoral fin rays. Environ. Biol. Fishes 90, 171-181. https://doi.org/10.1007/s10641-010-9728-4.

Kennedy, B.P., Blum, J.D., Folt, C.L., Nislow, K.H., 2000. Using natural strontium isotopic signatures as fish markers: methodology and application. Can. J. Fish. Aquat. Sci. 57, 2280-2292. https://doi.org/10.1139/f00-206.

Köck, G., Noggler, M., Hofer, R., 1996. Pb in otoliths and opercula of arctic char (Salvelinus alpinus) from oligotrophic lakes. Water Res. 30, 1919-1923. https://doi. org/10.1016/0043-1354(96)00074-7.

Lana, P.C., Marone, E., Lopes, R.M., Machado, E.C., 2001. The subtropical estuarine complex of Paranaguá Bay. Braz. Ecol. Stud. 144, 131-145. https://doi.org/10.1007/
978-3-662-04482-7_11.

Luchini, L., 1984. Estudios ecologicos de la cuenca del Río Limay. Rev. Asoc. Cienc. Nat. Litoral. 12, 55-58.

Luque, P.L., Zhang, S., Rooker, J.R., et al., 2017. Dorsal fin spines as a non-invasive alternative calcified structure for microelemental studies in Atlantic bluefin tuna. J. Exp. Mar. Biol. Ecol. 486, 127-133. https://doi.org/10.1016/j.jembe.2016.09.016.

Olejnik, S.F., Algina, J., 1984. Parametric ANCOVA and the rank transform ANCOVA when the data are conditionally non-normal and heteroscedastic. J. Educ. Behav. Stat. 9, 129-149. https://doi.org/10.3102/10769986009002129.

Paton, C., Hellstrom, J., Paul, B., et al., 2011. Iolite: freeware for the visualisation and processing of mass spectrometric data. J. Anal. At. Spectrom. 26, 2508. https://doi. org/10.1039/c1ja10172b.

Phelps, Q.E., Whitledge, G.W., Tripp, S.J., et al., 2012. Identifying river of origin for age-0 Scaphirhynchus sturgeons in the Missouri and Mississippi rivers using fin ray microchemistry. Can. J. Fish. Aquat. Sci. 69, 930-941. https://doi.org/10.1139/f2012038.

Pohl, C., Hirsch Hadorn, G., 2008. Methodological challenges of transdisciplinary research. Nat. Sci. Soc. 16, 111-121. https://doi.org/10.1051/nss:2008035.

Pourang, N., Haghighi, F.P., Moazami, H.R., 2018. Hard parts chemical composition as a potentially valuable tool for kutum, Rutilus kutum stock discrimination: a case study of the Southern Caspian Sea. Estuar. Coast. Shelf Sci. 207, 194-202. https://doi.org/ 10.1016/j.ecss.2018.04.014

Reis, E.G., 1986. Age and growth of the marine catfish, Netuma barba (Siluriformes, Ariidae), in the estuary of the Patos Lagoon (Brazil). Fish. Bull. 84, 679-686.

Ronco, A., Peluso, L., Jurado, M., et al., 2008. Screening of sediment pollution in tributaries from the Southwestern Coast of the Río de la Plata Estuary. Lat. Am. J. Sedimentol. Basin Anal. 15, 67-75.

Rude, N.P., Smith, K.T., Whitledge, G.W., 2014. Identification of stocked muskellunge and potential for distinguishing hatchery-origin and wild fish using pelvic fin ray microchemistry. Fish. Manag. Ecol. 21, 312-321. https://doi.org/10.1111/fme. 12081.

Smith, K.T., Whitledge, G.W., 2010. Fin ray chemistry as a potential natural tag for smallmouth bass in northern Illinois Rivers. J. Freshw. Ecol. 25, 627-635. https:// doi.org/10.1080/02705060.2010.9664412.

Smith, W.D., Miller, J.A., Heppell, S.S., 2013. Elemental markers in Elasmobranchs: effects of environmental history and growth on vertebral chemistry. PLoS One 8, e62423. https://doi.org/10.1371/journal.pone.0062423.

Tórz, A., Nędzarek, A., 2013. Variability in the concentrations of $\mathrm{Ca}, \mathrm{Mg}, \mathrm{Sr}, \mathrm{Na}$, and $\mathrm{K}$ in the opercula of perch (Perca fluviatilis L.) in relation to the salinity of waters of the Oder Estuary (Poland). Oceanol. Hydrobiol. Stud. 42, 1897-3191. https://doi.org/ 10.2478/s13545-013-0061-3.

Trembaczowsk, A., Niezgoda, H., 2011. Relationship between isotope composition of sulphur in sulphate dissolved in river water and sulphur extracted from fish scales. Isotopes Environ. Health Stud. 47, 189-213. https://doi.org/10.1080/10256016. 2011.572166.

Tzadik, O.E., Curtis, J.S., Granneman, J.E., et al., 2017. Chemical archives in fishes beyond otoliths: a review on the use of other body parts as chronological recorders of microchemical constituents for expanding interpretations of environmental, ecological, and life-history changes. Limnol. Oceanogr. Methods 15, 238-263. https://doi. org/10.1002/lom3.10153.

Veinott, G., Northcote, T., Rosenau, M., Evans, R.D., 1999. Concentrations of strontium in the pectoral fin rays of the white sturgeon (Acipenser transmontanus) by laser ablation sampling - inductively coupled plasma - mass spectrometry as an indicator of marine migrations. Can. J. Fish. Aquat. Sci. 56, 1981-1990. https://doi.org/10.1139/f99120.

Velasco, G., Reis, E.G., Vieira, J.P., 2007. Calculating growth parameters of Genidens barbus (Siluriformes, Ariidae) using length composition and age data. J. Appl Ichthyol. 23, 64-69. https://doi.org/10.1111/j.1439-0426.2006.00793.x.

Villar, C., Stripeikis, J., D'Huicque, L., et al., 1999a. Cd, Cu and Zn concentrations in sediments and the invasive bivalves Limnoperna fortunei and Corbicula fluminea at the Río de la Plata basin, Argentina. Hydrobiologia 416, 41-49. https://doi.org/10. 1023/A:1003811223880.

Villar, C., Stripeikis, J., Tudino, M., et al., 1999b. Trace metal concentrations in coastal marshes of the Lower Paraná River and the Río de la Plata Estuary. Hydrobiologia 397, 187-195.

White, J., Ruttenberg, B., 2007. Discriminant function analysis in marine ecology: some oversights and their solutions. Mar. Ecol. Prog. Ser. 329, 301-305. https://doi.org/ 10.3354/meps329301.

Wolff, B.A., Johnson, B.M., Landress, C.M., 2013. Classification of hatchery and wild fish using natural geochemical signatures in otoliths, fin rays, and scales of an endangered catostomid. Can. J. Fish. Aquat. Sci. 70, 1775-1784. https://doi.org/10.1139/cjfas2013-0116.

Yamada, S., Mulligan, T.J., Fournier, D., 1987. Role of environment and stock on the elemental composition of sockeye salmon (Oncorhynchus nerka) vertebrae. Can. J. Fish. Aquat. Sci. 44, 1206-1212. https://doi.org/10.1139/f87-143. 